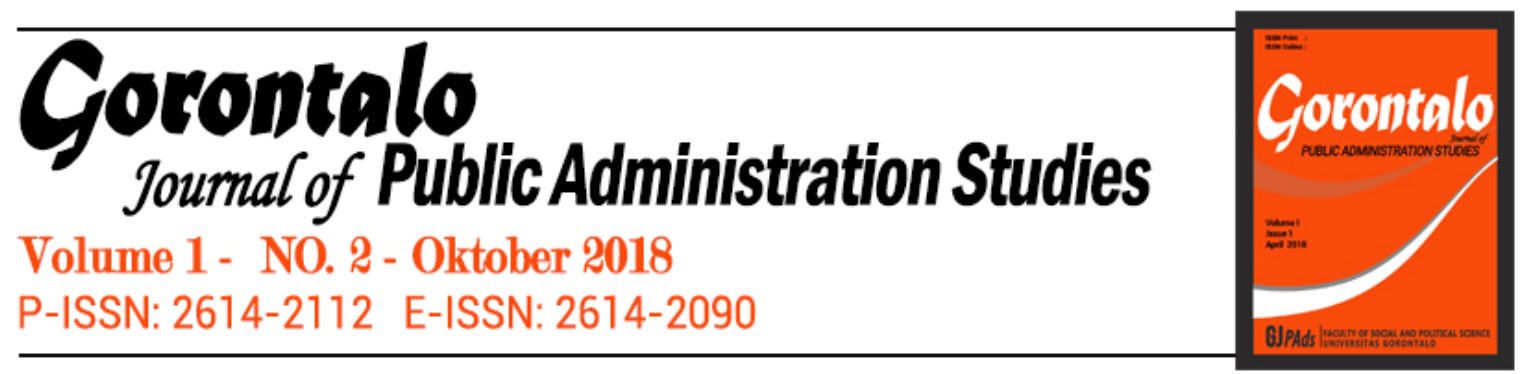

\title{
Implementasi Kebijakan Kepala Desa dalam Pengelolaan Anggaran Pendapatandan Belanja Desa (APBDes)
}

\author{
Nirmala Afrianti Sahi \\ Administrasi Publik Universitas Gorontalo \\ Jalan A.A. Wahab, No. 247, Limboto \\ nirmalaathirah@gmail.com
}

\begin{abstract}
In the context of village development, Butu Village is interesting to analyze because this village still has 93 poor households in 2016 that must be solved by the Butu Village government. Then the number of target households receiving recipients of poverty alleviation programs such as Raskin assistance was 94 families, BLSM 72 families, PKH 56 families, Jamkesmas 429 people, and Jamkesda 163 people. Given that in terms of income, Butu Village gets a large budget allocation managed by the Village Government in the form of Regional Budget. But on the other hand the financial management and wealth owned by the village must correlate with poverty alleviation in Butu village, but it has not yet been fully realized.

This research is in the form of qualitative research, where this research will explain in depth about the mechanism of management of the Butu Village Revenue and Expenditure Budget. The government of Bone Bolango Regency must improve the supervision aspects; financial management in villages, poorly managed village complaints channels by the Regional Government; and the unclear scope of the evaluation of supervision carried out by the subdistrict head.
\end{abstract}

Keywords: Village Policy: APBDS.

\begin{abstract}
ABSTRAK
Dalam konteks pengembangan desa, Desa Butu menarik untuk dianalisis sebab desa ini masih terdapat 93 rumah tangga miskin tahun 2016 yang harus dipecahkan oleh pemerintah Desa Butu. Kemudian banyaknya rumah tangga sasaran penerima program pengentasan kemiskinan seperti bantuan Raskin sebanyak 94 KK, BLSM 72 KK, PKH 56 KK, Jamkesmas 429 Jiwa, dan Jamkesda 163 jiwa. Mengingat dari segi pendapatan, Desa Butu ini mendapatkan alokasi anggaran yang besar yang dikelola olem Pemerintah Desa dalam bentuk APBDes. Namun disisi yang lain pengelolaan keuangan dan kekayaan yang dimiliki desa harus berkorelasi dengan pengentasan kemiskinan didesa Butu, namun belum sepenuhnya diwujudkan.

Penelitian ini berbentuk penelitian Kualitatif, dimana penelitian ini akan menjelaskan secara mendalam perihal mekanisme pengelolaan Anggaran Pendapatan dan Belanja Desa Butu.Pemerintah Kabupaten Bone Bolango harus meningkatkan aspek pengawasan terdapat tiga potensi persoalan yang dihadapi, yakni Masih rendahnya efektivitas inspektorat daerah Bone Bolango dalam melakukan pengawasan terhadap pengelolaan keuangan di desa, Tidak terkelolanya dengan baik saluran pengaduan masyarakat desa oleh Pemerintah Daerah; dan Belum jelasnya ruang lingkup evaluasi dari pengawasan yang dilakukan oleh camat.
\end{abstract}

Kata Kunci : Kebijakan Desa; APBDS. 


\section{PENDAHULUAN}

Lahirnya UU Nomor 6 Tahun 2014 tentang desa tentang Desa sangat jelas mengatur tentang pemerintahan desa, termasuk didalamnya tentang kewenangan dalam pengelolaan keuangan desa oleh Pemerintah Kabupaten/Kota untuk merumuskan dan membuat peraturan daerah tentang Alokasi Dana Desa (ADD) serta pelimpahan kewenangan lainnya sebagai bagian dari kewenangan fiskal desa untuk mengatur dan mengelola keuangan dan pembangunannya.

Berbagai kelemahan dalam UU dan peraturan pemerintah tentang desa, mendorong Pemerintah melakukan revisi terhadap UU tersebut dan melahirkan UU yang baru yakni memecah UU 32 Tahun 2004 menjadi 3 UU yakni, UU Nomor 23 Tahun 2014 tentang Pemerintahan Daerah, UU Nomor 10 Tahun 2015 Tentang Pilkada dan UU Nomor 6 Tahun 2014 Tentang Desa. Desa sendiri jika sebelumnya hanya diatur oleh Peraturan Pemerintah kini diatur oleh UU tersendiri yakni UU Nomor 6 Tahun 2014 tentang desa serta Peraturan Pemerintah Nomor 43 tahun 2014 tentang peraturan pelaksanaan UU Nomor 6 tahun 2014 tentang Desa.

Dalam UU Nomor 6 Tahun 2014 disebutkan bahwa Kewenangan Desa meliputi kewenangan di bidang penyelenggaraan Pemerintahan Desa, pelaksanaan Pembangunan Desa, pembinaan kemasyarakatan Desa, dan pemberdayaan masyarakat Desa berdasarkan prakarsa masyarakat, hak asal usul, dan adat istiadat Desa. Pemerintah Desa memiliki kewenangan memimpin penyelenggaraan Pemerintahan Desa, mengangkat dan memberhentikan perangkat Desa, memegang kekuasaan pengelolaan Keuangan dan Aset Desa, menetapkan Peraturan Desa, menetapkan Anggaran Pendapatan dan Belanja Desa, membina kehidupan masyarakat Desa dan membina ketenteraman dan ketertiban masyarakat Desa.

Selain itu pemerintah desa berwewenang membina dan meningkatkan perekonomian Desa serta mengintegrasikannya agar mencapai perekonomian skala produktif untuk sebesar-besarnya kemakmuran masyarakat Desa, mengembangkan sumber pendapatan Desa, mengusulkan dan menerima pelimpahan sebagian kekayaan negara guna meningkatkan kesejahteraan masyarakat Desa, mengembangkan kehidupan sosial budaya masyarakat Desa, memanfaatkan teknologi tepat guna, mengoordinasikan Pembangunan Desa secara partisipatif, mewakili Desa di dalam dan di luar pengadilan atau menunjuk kuasa hukum untuk mewakilinya sesuai dengan ketentuan peraturan perundang-undangan, dan melaksanakan wewenang lain yang sesuai dengan ketentuan peraturan perundang-undangan.

Perihal kewenangan dalam mengelola keuangan desa dilaksanakan berdasarkan Peraturan Menteri Dalam Negeri Nomor 113 Tahun 2014. Pengelolaan keuangan serta segala potensi yang terdapat didesa menjadi wewenang pemerintah desa. Hal ini dimaksudkan agar segala potensi yang meiluti kekayaan desa dapat digunakan dengan mengedepankan transfaransi dan akuntabilitas. sehingga dengan demikian timbul kepercayaan dari masyarakat terhadap pemerintah desa.

Kekayaan yang dimiliki desa termasuk keungan desa, Dana Desa dan Alokasi Dana Desa serta berbagai pendapatan yang bersumber dari pendapatan asli desa seperti dari hasil usaha desa, hasil kekayaan desa, hasil swadaya dan partisipasi, hasil gotong royong, dan lain-lain pendapatan asli desa yang sah, 
pengelolaan segala keuangan akan dianalisis apakah sejauh ini pengelolaannya sudah sesuai dengan Peraturan Menteri Dalam Negeri Nomor 113 Tahun 2014.

Dalam konteks tersebut di Desa Butu menarik untuk dianalisis sebab desa ini masih terdapat 93 rumah tangga miskin tahun 2016 yang harus dipecahkan oleh pemerintah Desa Butu. Kemudian banyaknya rumah tangga sasaran penerima program pengentasan kemiskinan seperti bantuan Raskin sebanyak 94 KK, BLSM 72 KK, PKH 56 KK, Jamkesmas 429 Jiwa, dan Jamkesda 163 jiwa. Mengingat dari segi pendapatan, Desa Butu ini mendapatkan alokasi anggaran yang besar yang dikelola olem Pemerintah Desa dalam bentuk APBDes. Namun disisi yang lain pengelolaan keuangan dan kekayaan yang dimiliki desa harus berkorelasi dengan pengentasan kemiskinan didesa Butu, namun belum sepenuhnya diwujudkan.

Lahirnya UU Nomor 6 Tahun 2014 tentang desa yang dikuti oleh PP 43 Tahun 2016, serta Permendagri Nomor 113 Tahun 2014 bertujuan untuk memajukan dan mensejahterakan masyarakt desa. Selain itu juga memberikan penguatan terhadap kewenangan pemerintah desa dalam mengelola SDA, SDM serta Sumber Daya Materi yang dimiliki desa.

Hasil pengamatan awal yang telah dilakukan oleh penulis di Desa ButuKecamatan Tilongkabila, didapatkan bahwa masih ada aparatur pemerintah desa yang belum bisa memahami subtansi dari Permendagri Nomor 113 tahun 2014 tentang Penelolaan Keuangan Desa, serta tujuan dan sasaran pengunaan keuangan desa.

\section{METODE PENELITIAN}

Dalam menganalisis Implementasi Kebijakan Kepala Kepala Desa dalam Pengelolaan Anggaran Pendapatan dan Belanja Desa (APBDes), sebagaimana berdasarkan Peraturan Menteri Dalam Negeri Nomor 113 tahun 2014 Tentang Pengelolaan Keuangan Desa, di Desa Butu Kecamatan Tilongkabila, penulis menggunakan metode penelitian Kualitatif.

Penggunaan metode ini dinilai tepat untuk menggali fakta dan informasi secara mendalam terhadap semua rangkaian aktivitas pemerintah Desa Butu selama 3 tahun sejak 2015 sampai dengan 2017. Penulisan ini tujuan untuk mendeskripsikan dan menganalisis proses Pengelolaan Anggaran Pendapatan Belanja Desa serta menganalisis permasalahan yang terjadi dalam pengelolaan APBDes desa di Desa Butu selama 3 tahun.

Selain itu bagian ini akan menguraikan metode penelitian yang akan digunakan untuk menganalisis masalah yang akan diteliti mulai dari Jenis Penelitian, Lokasi Penelitian, Teknik Pengumpulan Data, Informan, Jenis dan Sumber Data dan Teknik Analisis Data sebagai berikut.

\section{Jenis Penelitian.}

Dalam menganalisis kebijakan pemerintah desa dalam pembentukan pengelolaan Anggaran Pendapatan dan Belanja Desa di Desa Butu Kecamatan Tilongkabila, Penulis menggunakan jenis penelitian Kualitatif. Jenis penelitian ini adalah penelitian deskriptif dengan menggunakan metode kualitatif. Penelitian kualitatif atau yang sering disebut sebagai metode penelitian naturalistik, karena penelitiannya dilakukan pada kondisi yang alamiah. Metode kualitatif digunakan untuk mendapatkan data yang mendalam, suatu data yang mengandung makna. Makna adalah data yang sebenarnya, data yang 
pasti yang merupakan suatu nilai di balik data yang tampak. Oleh karena itu dalam penelitian kualitatif tidak menekankan pada generalisasi, tetapi lebih menekankan pada makna.

Metode penelitian kualitatif adalah adalah metode penelitian yang digunakan untuk meneliti pada kondisi objek yang alamiah. Hasil penelitian kualitatif lebih menekankan makna dari pada generalisasi. Penelitian ini berbentuk penelitian Kualitatif, dimana penelitian ini akan menjelaskan secara mendalam perihal mekanisme pengelolaan Anggaran Pendapatan dan Belanja Desa Butu.

\section{Lokasi Penelitian.}

Lokasi penelitian ini berada diwilayah Kabupaten Bone Bolango tepatnya berada di Kecamatan Tilongkabila Desa Butu dengan memusatkan pada tempat di Kantor Desa Butu.

\section{Teknik Pengumpulan Data.}

Teknik pengumpulan data yang digunakan mempunyai korelasi terhadap judul dan sesuai dengan data yang diperlukan antara lain :

1. Indepth Interview (Wawancara mendalam).

Sebelum peneliti ke objek yang dituju idealnya memformulasikan secara baik daftar yang merupakan inti permasalahan yang inginkan, sehingga para informan mudah memahami subtansi atas objek penelitian yang diajukan peneliti.

2. Dokumentasi.

Teknik pengumpulan data ini dilakukan untuk mendokumentasikan semua data dan informasi yang diperoleh dilapangan, hal ini ditujukan untuk lebih memudahkan melihat implentasi kebijakan pengelolaan APBDes Desa Butu dengan menganalisa data yang didokumentasikan. Selain itu mengetahui lebih mendalam suatu masalah berdasarkan data yang ada.

\section{Informan.}

Dalam penelitian kualitatif ini peneliti menggunakan istilah situasi sosial, karena penelitian kualitatif berangkat dari kasus tertentu yang ada pada situasi sosial tertentu dan hasil kajiannya tidak diberlakukan ke populasi, tetapi ditransferkan ketempat lain pada situasi sosial yang memiliki kesamaan dengan situasi sosial kasus yang dipelajari. Sampel dalam penelitian kualitatif ini bukan dinamakan responden, tetapi dinamakan sebagai nara sumber, atau partisipan, informan, teman dan guru dalam penelitian.

Pada penelitian kualitatif, peneliti memasuki situasi sosial tertentu, melakukan observasi dan wawancara kepada orang-orang yang dipandang mengetahui tentang situasi sosial tersebut. Penentuan sumber data pada orang yang diwawancarai dilakukan secara purposive, yaitu dipilih dengan pertimbangan dan tujuan tertentu.

Penentuan informan tidak dilakukan secara acak karena sudah ditentukan terlebih dahulu. Informan dan nara sumber penelitian ini ialah para penyelengara pemerintahan desa Butu. Selain aparat desa, ada pula pihak lainnya yang dijadikan informan walaupun tidak terlibat secara langsung tetapi mengetahui informasi dan memiliki data terkait persoalan dimaksud. I

Adapun teknik penentuan informan dalam penelitian ini adalah melalui pendekatan purposive, dan sebagai informan pada penelitian ini ialah: 
1. Kepala Desa Butu;

2. Ketua BPD Butu;

3. Sekretaris Desa Butu;

4. Kepala Urusan Pemerintahan Desa Butu;

5. Bendahara Desa Butu;

6. Tokoh masyarakat Desa Butu.

Jumlah informan pada penelitian ini sangat dimungkinkan akan bertambah sesuai dengan kebutuhan informasi dan data yang diperlukan oleh penulis sesuai kondisi dilapangan.

\section{HASIL PENELITIAN DAN PEMBAHASAN}

Pada bagian ini penulis akan mengurai dan membahas temuan hasil penelitian terhadap dua pokok masalah yakni pertama kebijakan Kepala Desa Butu dalam pengelolaan Anggaran Pendapatan Belanja Desa. Kedua perihal pengelelolaan APBDes, apakah sudah sesuai dengan Permendagri Nomor 113 Tahun 2014 tentang pengelolaan Keuangan Desa.

\section{Kebijakan Kepala Desa Butu Kecamatan Tilongkabila Dalam Pengelolaan Anggaran Pendapatan Belanja Desa (APBDes).}

Sebagaimana dalam UU Nomor 6 Tahun 2014 tentang Desa dijelaskan bahwa Pemegang Kekuasaan Pengelolaan Keuangan Desa adalah Kepala Desa atau sebutan nama lain yang karena jabatannya mempunyai kewenangan menyelenggarakan keseluruhan pengelolaan keuangan desa. Pelaksana Teknis Pengelolaan Keuangan Desa yang selanjutnya disingkat PTPKD adalah unsur perangkat desa yang membantu Kepala Desa untuk melaksanakan pengelolaan keuangan desa.

Selanjutnya posisi aparatur pemerintah desa yang terdiri dari Sekretaris, Bendahara, Kepala Seksi memiliki kewenangan yakni, Sekretaris Desa adalah bertindak selaku koordinator pelaksanaan pengelolaan keuangan desa. Kepala Seksi adalah unsur dari pelaksana teknis kegiatan dengan bidangnya. Bendahara adalah unsur staf sekretariat desa yang membidangi urusan pengeloaan keuangan.

Kemudian dalam Undang-Undang ini mengatur materi mengenai kekuasaan Kepala Desa dalam Mengelola Keuangan Desa, serta kewenangan sekretaris desa sebagai koordinator pelaksana teknis pengelola keuangan desa. Keuangan desa yang dimaksud dalam peraturan ini adalah pendapatan desa, belanja desa dan pembiayaan desa.

Dalam peraturan Menteri Dalam Negeri Nomor 113 Tahun 2014 disebutkan bahwa yang dimaksud dengan Anggaran Pendpatan dan Belanja Desa atau APBDes terdiri atas: Pendapatan Desa; Belanja Desa; dan Pembiayaan Desa. Yang dimaksud dengan Pendapatan Desa meliputi meliputi semua penerimaan uang melalui rekening desa yang merupakan hak desa dalam 1 (satu) tahun anggaran yang tidak perlu dibayar kembali oleh desa. Pendapatan Desa sebagaimana dimaksud dalam Pasal 8 ayat $(1)$, terdiri atas kelompok: Pendapatan Asli Desa (PADesa), Transfer, dan Pendapatan Lain-Lain. Sedangkan Kelompok PADesa sebagaimana dimaksud dalam Permendagri Nomor 113 Tahun 2014 terdiri atas jenis: Hasil usaha, Hasil aset; Swadaya, partisipasi dan Gotong royong; dan Lain-lain pendapatan asli desa. 
Hasil usaha desa sebagaimana dimaksud antara lain hasil Bumdes, tanah kas desa. Hasil aset sebagaimana dimaksud antara lain tambatan perahu, pasar desa, tempat pemandian umum, jaringan irigasi. Swadaya, partisipasi dan gotong royong sebagaimana dimaksud adalah membangun dengan kekuatan sendiri yang melibatkan peran serta masyarakat berupa tenaga, barang yang dinilai dengan uang. Kelompok transfer sebagaimana terdiri atas jenis, Dana Desa, Bagian dari Hasil Pajak Daerah Kabupaten/Kota dan Retribusi Daerah, Alokasi Dana Desa (ADD), Bantuan Keuangan dari APBD Provinsi, dan Bantuan Keuangan APBD Kabupaten/Kota.

Kemudian Belanja desa sebagaimana dimaksud diatas meliputi semua pengeluaran dari rekening desa yang merupakan kewajiban desa dalam 1 (satu) tahun anggaran yang tidak akan diperoleh pembayarannya kembali oleh desa. Klasifikasi Belanja Desa terdiri atas kelompok Penyelenggaraan Pemerintahan Desa, Pelaksanaan Pembangunan Desa, Pembinaan Kemasyarakatan Desa, Pemberdayaan Masyarakat Desa dan Belanja Tak Terduga. Kelompok belanja dibagi dalam kegiatan sesuai dengan kebutuhan Desa yang telah dituangkan dalam RKPDesa. Dimana Kegiatan terdiri atas jenis belanja Pegawai, belanja Barang dan belanja Jasa, serta belanja Modal.

Selang tahun 2014 sampai dengan tahun 2017 berbagai pembangunan di Desa Butu Kecamatan Tilongkabila adalah sebagai berikut :

Tabel . 1.2

Program Pembangunan Desa Butu Tahun 2014-2017

\begin{tabular}{|c|c|c|c|l|}
\hline No. & Tahun & $\begin{array}{c}\text { Sumber } \\
\text { Dana }\end{array}$ & Jumlah Anggran & Jenis Pembangunan \\
\hline 1. & TA. 2014 & APBDes & Rp. 126.980.000 & Mahyani 2 Unit \\
\hline 2. & TA. 2015 & APBDes & Rp. 270.548.616 & $\begin{array}{l}\text { Jalan Rabat Beton, } \\
\text { Drainase, Plat Duicker }\end{array}$ \\
\hline 3. & TA. 2016 & APBDes & Rp. 951.708.824 & $\begin{array}{l}\text { Mahyani 3 unit, } \\
\text { jamban Keluraga 20 } \\
\text { Unit, Jln. Rabat } \\
\text { Benton, Saluran } \\
\text { Irigasi. }\end{array}$ \\
\hline 4. & TA. 2017 & APBDes & 1.130.980.412 & $\begin{array}{l}\text { Jalan Desa, Saluran } \\
\text { Irigasi, Sarana Air } \\
\text { Bersih, Sarana Sanitasi } \\
\text { dan Kebersihan } \\
\text { Lingkungan, 25 Unit } \\
\text { Jamban Keluarga. }\end{array}$ \\
\hline
\end{tabular}

Berdasarkan data hasil penelitian ditemukan sejumlah persoalan yang terjadi dalam aspek penggunaan APBDes Desa Butu, dimana data diatas menunjukan bahwa Program Pembangunan di desa tersebut sejak tahun 2014 sampai dengan 2017, sama sekali tidak menyentuh upaya mengentaskan permasalahan kemiskinan di desa yang masih mencapai 177 Kepala Keluarga miskin. Sejak tahun 2014 Pemdes Butu hanya mampu membuat 2 buah mahyani, kemudian pada tahun 2015 membuat jalan rabat beton, drainase dan Plat Duiker. Sedangkan tahun 2016 ketika desa ini mulai mendapatkan dana desa melalui APBN, hanya mampu membuat 3 unit mahyani, 20 unit jamban 
keluarga, jalan rabat beton dan saluran irigasi. Kemudian tahun 2017 membuat jalan desa, saluran irigasi, sarana air bersih, sarana sanitasi, 25 unit jamban keluarga.

Penggunaan dan pengelolaan Dana Desa melalui APBDes di Desa Butu kecamatan Tilongkabila dinilai tidak mampu menyentuh subtansi pembangunan terutama untuk meningkatkan perekonomian masyarakat desa maupun pengentasan kemiskinan. Berdasarkan hasil penelitian, ditemukan beberapa masalah dalam pengelolaan Anggaran Pendapatan Belanja Desa (APBDes) di Desa Butu Kecamatan Tilongkabila terdiri dari:
a. aspek regulasi kelembagaan,
b. aspek tata laksana,
c. aspek pengawasan, dan
d. aspek sumber daya manusia.

Aspek regulasi kelembagaan terdiri dari belum lengkapnya regulasi dan petunjuk teknis pelaksanaan keuangan desa, potensi tumpang tindih kewenangan Kemendes PDT dengan Ditjen Bina Pemerintah Desa Kemendagri, tidak transparannya formula pembagian dana desa dalam Peraturan Pemerintah (PP) Nomor 22 tahun 2015 dan hanya didasarkan atas dasar pemerataan.

Selain itu, pengaturan pembagian penghasilan tetap bagi perangkat desa dari anggaran dana desa (ADD) yang diatur dalam PP Nomor 43 tahun 2014 dinilai kurang berkeadilan serta kewajiban penyusunan laporan pertanggungjawaban oleh desa yang tidak efisien akibat ketentuan regulasi dan tumpang tindih.Persoalan yang cukup mencolok, adalah formula pembagian dana desa yang berubah. misalnya sesuai formula PP No. 60/2014, Desa A dengan luas $7,5 \mathrm{~km}$ persegi dan memiliki 21 dusun akan mendapat dana desa Rp437 juta, sedangkan Desa B dengan luas Rp1,5 km dan memiliki 3 dusun maka mendapat dana Rp41 juta. Namun dengan peraturan baru PP No. 22/2015 Desa A dapat Rp312 juta dan B Rp263 juta.

Dalam hasil analisis penulis ada lima persoalan yang ditemukan dari segi pelaksanaan yaitu :

1. Kerangka pengelolaan anggaran desa sulit dipatuhi oleh desa.

2. belum tersedianya atuan harga baku barang atau jasa yang dijadikan acuan bagi desa dalam menyusun APBDesa.

3. masih rendahnya transparansi rencana penggunaan dan pertanggungjawaban APBDesa.

a. laporan pertanggung jawaban yang dibuat desa belum mengikuti standar dan rawan manipulasi.

b. APBDes yang disusun tidak sepenuhnya menggambarkan kebutuhan yang diperlukan desa.

c. Desa Butu yang minim infrastruktur dan proporsi jumlah penduduk mayoritas miskin, justru memprioritaskan penggunaan APBDes untuk belanja aparatur desa yang kondisinya masih relatif baik.

Ada beberapa temuan yang ditemukan oleh penulismisalnya masalah pengelolaan keuangan desa di Desa Butu. Yaitu :

a. Surat pertanggungiawaban penggunaan keuangan desa terlambat dibuat atau belum tertib.

b. Bendahara desa belum melakukan pemungutan pajak.

c. Bukti pengeluaran uang belum memenuhi keabsahan.

d. Volume pekerjaan belum sesuai dengan rencana. 
e. Transparansi pengelolaan dana desa masih kurang, mulai dari perencanaan, pelaksanaan, dan pertanggungjawaban.

f. Aspek sumber daya manusia terdapat potensi persoalan yakni tenaga pendamping berpotensi melakukan korupsi dengan memanfaatkan lemahnya aparat desa.

Adanya permasalahan tersebut hendaknya menjadi bahan evaluasi bagi seluruh pihak terkait terutama Pemerintah Kabupaten Bone Bolango agar pengelolaan dana desa menjadi lebih baik. Harus ada upaya mengatasi berbagai masalah yang ada agar penyaluran dan penggunaan dana desa bisa berjalan dengan lancar dan bisa memberikan kemanfaatan bagi pembangunan dan pemberdayaan desa.

Sedangkan pada aspek pengawasan terdapat tiga potensi persoalan yang dihadapi, yakni

1. Masih rendahnya efektivitas inspektorat daerah Bone Bolango dalam melakukan pengawasan terhadap pengelolaan keuangan di desa,

2. Tidak terkelolanya dengan baik saluran pengaduan masyarakat desa oleh Pemerintah Daerah; dan

3. Belum jelasnya ruang lingkup evaluasi dari pengawasan yang dilakukan oleh camat.

\section{Pengeloaan APBDes di Desa Butu dalam tinjauan Permendagri Nomor 113 Tahun 2014 Tentang Pengelolaan Keuangan.}

Berdasarkan hasil penelitian ditemukan pola dan mekanisme pengelolaan APBDes Desa Butu Kecamatan Tilongkabila sebagai berikut : Sekretaris Desa menyusun Rancangan Peraturan Desa tentang APBDesa berdasarkan RKPDesa tahun berkenaan. Kemudian Sekretaris Desa menyampaikan rancangan Peraturan Desa tentang APBDesa kepada Kepala Desa.

Rancangan peraturan Desa tentang APBDesa sebagaimana dimaksud pada ayat (2) Permendagri Nomor 113 Tahun 2014 bahwa Perda APBDes disampaikan oleh Kepala Desa kepada Badan Permusyawaratan Desa untuk dibahas dan disepakati bersama. Rancangan Peraturan Desa tentang APBDesa disepakati bersama sebagaimana dimaksud pada ayat (3) paling lambat bulan Oktober tahun berjalan.

Rancangan Peraturan Desa tentang APBDesa yang telah disepakati bersama disampaikan oleh Kepala Desa kepada Bupati melalui camat paling lambat 3 (tiga) hari sejak disepakati untuk dievaluasi. Kemudian Bupati menetapkan hasil evaluasi Rancangan APBDesa paling lama 20 (dua puluh) hari kerja sejak diterimanya Rancangan Peraturan Desa tentang APBDesa. Apabila Bupati tidak memberikan hasil evaluasi dalam batas waktu sebagaimana dimaksud maka Peraturan Desa tersebut berlaku dengan sendirinya.

Selanjutnya Bupati menyatakan hasil evaluasi Rancangan Peraturan Desa tentang APBDesa tidak sesuai dengan kepentingan umum dan peraturan perundang-undangan yang lebih tinggi, Kepala Desa melakukan penyempurnaan paling lama 7 (tujuh) hari kerja terhitung sejak diterimanya hasil evaluasi. Namun apabila hasil evaluasi tidak ditindaklanjuti oleh Kepala Desa sebagaimana dimaksud dalam Pasal 21 ayat (4) dan Kepala Desa tetap menetapkan Rancangan Peraturan Desa tentang APBDesa menjadi Peraturan Desa, Bupati membatalkan Peraturan Desa Tentang APBDes dengan Keputusan 
Bupati. Pembatalan Peraturan Desa APBDes sebagaimana dimaksud sekaligus menyatakan berlakunya pagu APBDesa tahun anggaran sebelumnya.

Jika hal pembatalan itu terjadi maka Kepala Desa hanya dapat melakukan pengeluaran terhadap operasional penyelenggaraan Pemerintah Desa. Kemudian Kepala Desa memberhentikan pelaksanaan Peraturan Desa Paling lama 7 (tujuh) hari kerja setelah pembatalan dan selanjutnya Kepala Desa bersama BPD mencabut peraturan desa dimaksud.

Bupati dapat mendelegasikan evaluasi Rancangan Peraturan Desa tentang APBDesa kepada camat. Camat menetapkan hasil evaluasi Rancangan APBDesa sebagaimana dimaksud paling lama 20 (dua puluh) hari kerja sejak diterimanya Rancangan Peraturan Desa tentang APBDesa. Apabila dalam hal Camat tidak memberikan hasil evaluasi dalam batas waktu, maka Peraturan Desa tersebut berlaku dengan sendirinya. Namun apabila Camat menyatakan hasil evaluasi Rancangan Peraturan Desa tentang APBDesa tidak sesuai dengan kepentingan umum dan peraturan perundang-undangan yang lebih tinggi, Kepala Desa melakukan penyempurnaan paling lama 7 (tujuh) hari kerja terhitung sejak diterimanya hasil evaluasi. Apabila hasil evaluasi tidak ditindaklanjuti oleh Kepala Desa dan Kepala Desa tetap menetapkan Rancangan Peraturan Desa tentang APBDesa menjadi Peraturan Desa, Camat menyampaikan usulan pembatalan Peraturan Desa kepada Bupati.

Penulis menemukan Semua penerimaan dan pengeluaran desa di Butu dalam rangka pelaksanaan kewenangan desa sebagaimana di amanatkan oleh UU Nomor 6 Tahun 2014 dan Permendagri Nomor 113 Tahun 2014, dilaksanakan melalui rekening kas desa. Pemerintah desa dilarang melakukan pungutan sebagai penerimaan desa selain yang ditetapkan dalam peraturan desa. Bendahara dapat menyimpan uang dalam Kas Desa pada jumlah tertentu dalam rangka memenuhi kebutuhan operasional pemerintah desa.

Pemerintah desa Butu telah melaksanakan ketentuan Permendagri 113 tahun 2014 terkait Pengeluaran desa yang mengakibatkan beban APBDesa, dimana Pemdes Butu tidak dapat menggunakan APBDes sebelum rancangan peraturan desa tentang APBDesa ditetapkan menjadi peraturan desa. Termasuk pengeluaran desa untuk kepentingan pembangunan terkecuali untuk belanja pegawai yang bersifat mengikat dan operasional perkantoran yang ditetapkan dalam peraturan kepala desa. Soal Penggunaan biaya tak terduga terlebih dulu harus dibuat Rincian Anggaran Biaya yang telah disahkan oleh Kepala Desa.

Dalam pengajuan pelaksanaan pembayaran, Sekretaris Desa berkewajiban untuk: a. meneliti kelengkapan permintaan pembayaran di ajukan oleh pelaksana kegiatan; b. menguji kebenaran perhitungan tagihan atas beban APBdes yang tercantum dalam permintaan pembayaran; c. menguji ketersedian dana untuk kegiatan dimaksud; dan d. menolak pengajuan permintaan pembayaran oleh pelaksana kegiatan apabila tidak memenuhi persyaratan yang ditetapkan. Berdasarkan SPP yang telah di verifikasi Sekretaris Desa, Kepala Desa menyetujui permintaan pembayaran dan bendahara melakukan pembayaran.

Pembayaran yang telah dilakukan, selanjutnya bendahara melakukan pencatatan pengeluaran. Bendahara desa sebagai wajib pungut pajak penghasilan $(\mathrm{PPh})$ dan pajak lainnya, wajib menyetorkan seluruh penerimaan potongan dan pajak yang dipungutnya ke rekening kas negara sesuai dengan ketentuan peraturan perundang-undangan. 
Selanjutnya apabila terjadi penambahan dan/atau pengurangan dalam pendapatan desa pada tahun berjalan; dan/atau terjadi peristiwa khusus, seperti bencana alam, krisis politik, krisis ekonomi, dan/atau kerusuhan sosial yang berkepanjangan; perubahan mendasar atas kebijakan Pemerintah dan Pemerintah Daerah, Perubahan APBDesa hanya dapat dilakukan 1 (satu) kali dalam 1 (satu) tahun anggaran.

Bendahara Desa wajib melakukan pencatatan setiap penerimaan dan pengeluaran serta melakukan tutup buku setiap akhir bulan secara tertib. Bendahara Desa wajib mempertanggungjawabkan uang melalui laporan pertanggungjawaban. Laporan pertanggungjawaban disampaikan setiap bulan kepada Kepala Desa dan paling lambat tanggal 10 bulan berikutnya.

Kepala Desa Butu menyampaikan laporan realisasi pelaksanaan APBDesa kepada Bupati Bone Bolango berupa:

a. laporan semester pertama; dan

b. laporan semester akhir tahun. Laporan semester pertama berupa laporan realisasi APBDesa.

c. Laporan realisasi pelaksanaan APBDesa disampaikan paling lambat pada akhir bulan Juli tahun berjalan.

d. Laporan semester akhir tahun disampaikan paling lambat pada akhir bulan Januari tahun berikutnya.

Kepala Desa Butuo setiap tahun anggaran menyampaikan laporan pertanggungjawaban realisasi pelaksanaan APBDesa kepada Bupati Bone Bolango setiap akhir tahun anggaran. Laporan pertanggungjawaban realisasi pelaksanaan APBDesa terdiri dari pendapatan, belanja, dan pembiayaan. Laporan pertanggungjawaban realisasi pelaksanaan APBDesa ditetapkan dengan Peraturan Desa. Peraturan Desa tentang laporan pertanggungjawaban realisasi pelaksanaan APBDesa sebagaimana dilampiri:

a. format Laporan Pertanggungjawaban Realisasi Pelaksanaan APBDesa Tahun Anggaran berkenaan;

b. format Laporan Kekayaan Milik Desa per 31 Desember Tahun Anggaran berkenaan; dan

c. format Laporan Program Pemerintah dan Pemerintah Daerah yang masuk ke desa.

Laporan realisasi dan laporan pertanggungjawaban realisasi pelaksanaan APBDesa Desa Butu diinformasikan kepada masyarakat secara tertulis dan dengan media informasi yang mudah diakses oleh masyarakat. Media informasi antara lain papan pengumuman, radio komunitas, dan media informasi lainnya.

Format Rancangan Peraturan Desa tentang APBDesa, Buku Pembantu Kas Kegiatan, Rencana Anggaran Biaya dan Surat Permintaan Pembayaran serta Pernyataan Tanggungjawab Belanja, Laporan Realisasi Pelaksanaan APBDesa pada semester pertama dan semester akhir tahun serta Laporan Pertanggungjawaban Realisasi Pelaksanaan APBDesa semuanya dijalankan dengan baik.

\section{PENUTUP \\ Kesimpulan}

Memperhatikan berbagai data dan informasi yang penulis dapatkan selama proses penelitian, maka dapat ditarik kesimpulan bahwa ditemukan beberapa 
masalah dalam pengelolaan Anggaran Pendapatan Belanja Desa (APBDes) di Desa Butu Kecamatan Tilongkabila terdiri dari:

1. Bahwa pemahaman terhadap regulasi Pengelolaan APBDes terutama Permendagri Nomor 113 Tahun 2014 Desa Butu masih lemah, hal ini karena disebakan oleh lemahnya Aspek regulasi kelembagaan, Aspek tata laksana, lemahnya Aspek pengawasan, dan rendahnya Aspek sumber daya manusia.

2. Aparat pemerintah Desa Butu, masih sulit untuk memahami regulasi dalam pengelolaan anggaran desa;

3. Belum tersedianya aturan harga baku barang atau jasa yang dijadikan acuan bagi desa dalam menyusun APBDesa,

4. Masih rendahnya transparansi rencana penggunaan dan pertanggungjawaban APBDesa.

5. Laporan pertanggung jawaban yang dibuat desa belum mengikuti standar dan rawan manipulasi.

6. Subtansi pengelolaan dan pemanfaatan APBDes di Desa Butu belum tepat sasaran terutama dalam menekan angka kemiskinan.

7. APBDes yang disusun tidak sepenuhnya menggambarkan kebutuhan yang diperlukan desa Butu.

\section{Saran}

Berdasarkan kesimpulan hasil penelitian atasAnalisis Kebijakan Kepala Desa Butu Kecamatan Tikongkabila Dalam Pengelolaan Anggaran Pendapatan Dan Belanja Desa (APBDes) " Studi Terhadap Permendagri Nomor 113 Tahun 2014 Tentang Pengelolaan Keuangan Desatersebut diatas, dikemukakan tiga saran, yakni:

1. Pemerintah Desa Butu harus memperkuat pemahaman terhadap regulasi Pengelolaan APBDes terutama Permendagri Nomor 113 Tahun 2014 Desa Butu masih lemah.

2. Pemerintah Kabupaten Bone Bolango harus meningkatkan aspek pengawasan terdapat tiga potensi persoalan yang dihadapi, yakni Masih rendahnya efektivitas inspektorat daerah Bone Bolango dalam melakukan pengawasan terhadap pengelolaan keuangan di desa, Tidak terkelolanya dengan baik saluran pengaduan masyarakat desa oleh Pemerintah Daerah; dan Belum jelasnya ruang lingkup evaluasi dari pengawasan yang dilakukan oleh camat.

3. Pemerintah Desa Butu dalam menyusun APBDes hendaknya fokus pada upaya peningkatan ekonomi masyarakat dan pengentasan kemiskinan.

\section{REFERENSI}

Ari Dwipayana dan Sutoro (Ed). 2003. Membangun Good Governance di Desa. IRE Press. Yogyakarta.

Asyukri Ibn Chamim dkk. Civic Education: Menuju Kehidupan Demokratis dan Berkeadaban. 2003 (edisi revisi). Penerbit PP Muhamadyah, LP3, dan The Asia Foundation. Jakarta.

Awang Azam. 2011. Sistem Pemerintahan Daerah di Indonesia. ALAFRIAU. Pekanbaru.

Burhan Bungin. 2004. Metode Penelitian Kualitatitf.Rajawali Press. Jakarta 
David Osborne dan Ted Gabbler. 1999. Mewirausahakan Birokrasi. PT Pustaka BP. Jakarta.

Dawam Raharjo. 2001. Ekonomi Desa dan Manajemen Pemerintahan Desa. Pasca Sarjana PLOD UGM. Yogyakarta. Makalan workshop "Desentralisasi dan Good Governance di Tingkat Desa".

Bambang Purwanto. 2001. Ekonomi dan Demokrasi Desa dalam Perspektif Sejarah. Pasca Sarjana PLOD UGM. Yogyakarta. Makalan workshop "Desentralisasi dan Good Governance di Tingkat Desa".

Lexy Moelong. 2003. Penelitian Kualitatif. PT, Rosda. Bandung

Loina Lalolo KP. Indikator dan Alat Ukur Prinsip Akuntabilitas, Transparansi, Partisipasi. 2003. Bapenas. Jakarta. Makalah.

Miftah Thoha. 2003. Birokrasi dan Politik Di Indonesia. Raja Grafindo. Jakarta

Masri Singarimbun dan Sofian Effendi. 1982. Metode Penelitian Survei. Penerbit LP3ES. Jakarta.

Sadu Wasistiono. 2006. Prospek Pengembangan Desa. Penerbit Fokus Media. Bandung.

Syarief Makhya. Ilmu Pemerintahan:Telaahan Awal. 2004. Jurusan Ilmu Pemerintahan FISIP Unila. Bandar Lampung. Buku ajar.

Syafuan Rozi Soebhan. Model Reformasi Birokrasi di Indonesia. 2000. LIPI. Jakarta. Makalah

Sugiyono. 2012.Metode Penelitian Kuantitatif Kualitatif dan $R \& D$, Bandung :Cv. Alvabeta.

Taliziduhu Ndraha. 2003. Kybernology I (Ilmu Pemerintahan Baru).Rineka Cipta. Jakarta

Jakarta.

\section{Peraturan-Peraturan :}

UU No. 32 Tahun 2004 tentang Pemerintahan Daerah

UU Nomor 23 Tahun 2014 Tentang Pemerintahan Daerah

UU Nomor 6 Tahun 2014 Tentang Desa

PP Nomor 43 Tahun 2014 tentang Peraturan Pelaksanaan Undang-Undang Nomor 6 Tahun 2014 Tentang Desa

Peraturan Menteri Dalam Negeri Republik Indonesia Nomor 111 Tahun 2014 Tentang Pedoman Teknis Peraturan Di Desa

Peraturan Menteri Dalam Negeri Republik Indonesia Nomor 113 Tahun 2014 Tentang Pengelolaan Keuangan Desa

Peraturan Menteri Dalam Negeri Republik Indonesia Nomor 114 Tahun 2014 Tentang Pedoman Pembangunan Desa 